Pereira, H. G. \& Travassos, J. (1952). J. gen. Microbiol. 7, 61-68

\title{
A Quantitative Agglutination Method for the Study of the Specific Agglutination of Micro-organisms
}

\author{
By H. G. PEREIRA* aND J. TRAVASSOS \\ Rickettsia Department, Institute Oswaldo Cruz, Brazil
}

\begin{abstract}
SUMMARY: A quantitative method for the study of the specific agglutination of micro-organisms is described. The degree of agglutination is estimated from the sedimentation curves of suspensions to which varying amounts of serum are added, which are compared with that of a control suspension without serum. The time of centrifugation required for sedimentation of $50 \%$ of the organisms in the serumsuspension mixtures related to the corresponding time for the control suspension gives the relative $50 \%$ sedimentation times which, within a certain region, show a linear relation with the amounts of serum used. The activity of sera is expressed by their agglutinin content and by their agglutinating capacity, given by the slope of the time-serum regression line.

Rickettsias of the typhus group and their corresponding sera are clearly distinguished by the method described. Proteus OX19 agglutinating sera of different origins (pregnant women, murine typhus and Proteus-immune rabbit), with the same agglutinating titre by the dilution method, are distinguished according to their origin by the quantitative method. The application of the method to the study of other groups of micro-organisms is suggested.
\end{abstract}

The study of the specific agglutination of bacteria, rickettsias and viruses by immune sera is usually made by the serial dilution method, and the results are expressed as the highest dilution of a serum which causes a standard degree of agglutination. To obtain greater uniformity and reproducibility of the results of such tests, Hedén (1946) described a method for the determination of the $50 \%$ end-point based on the method of Reed \& Muench (1938) for the evaluation of end-points in animal tests. This method has the advantage of taking into consideration a number of dilutions for the evaluation of the titre but it suffers from the influence of the personal bias which may be considerable when agglutination tests are read by different workers. The method described by Hirst \& Pickles (1942) for the study of virus haemagglutination, if applied to the study of the agglutination of micro-organisms, as suggested by Kabat \& Mayer (1948), would probably yield valuable results. In this test, the degree of agglutination in individual tubes is estimated by measuring the density of the layer of unsedimented cells after a fixed period of time, and the course of the haemagglutination is translated by a sigmoid curve. In our experience (unpublished data) a similar type of curve was observed for bacterial and rickettsial agglutination. A great advance in the study of the agglutination reaction was made with the introduction of the chemical quantitative method of Heidelberger \& Kabat $(1934 a, b)$ in which the amount of antibody combined with agglutinated bacteria is measured by weight. This method, making possible the study of the course of bacterial agglutination as a function of

* Present address : Common Cold Research Unit, Harvard Hospital, Salisbury, Wilts. 
antigen and antibody, is a valuable tool for research, but its practical applications are limited by the technical difficulties involved.

In the present paper we describe a method in which the degree of agglutination is estimated by the sedimentation curves of suspensions to which various amounts of serum are added; these are compared with the sedimentation curve of a control suspension without serum. The sedimentation curves are built by reading the light extinction of suspensions in a photoelectric colorimeter after successive periods of centrifugation. The term sedimentation is used in a wide sense, as the variations of the light extinction depend both on the sedimentation proper and on the aggregation of the organisms. In such tests, a linear relationship is observed, within a certain range, between the amount of antibody present and the relative time necessary for $50 \%$ of the bacteria or rickettsias to be deposited.

\section{MATERIAL AND METHODS}

\section{Antigens}

Rickettsial suspensions were prepared from infected chick embryo yolk-sacs, purified by ether treatment and differential centrifugation. Murine (Wilmington strain) and classical (Breinl strain) typhus suspensions were prepared by method 2 of Topping \& Shepard (1946). The suspension of Q fever rickettsias was prepared by method 1 of the same authors. The suspensions were washed shortly before use by two centrifugations in an angle-head centrifuge at 4000 r.p.m. for $1 \mathrm{hr}$. and re-suspended in $0.2 \%$ formalized $0.005 \mathrm{M}$ phosphatebuffered ( $\mathrm{pH} \mathrm{7 \cdot 3)}$ saline (Kent, Bukants \& Rein, 1946), the diluent used throughout. The density of the suspensions was adjusted so as to give, when diluted 1/10, a light extinction reading of 50 .

Bacterial suspension. Ethanol-treated suspension of Proteus OX 19 was prepared according to the method of Bridges (1944). The density was adjusted so as to give, when diluted 1/10, a light extinction reading of 100 .

\section{Sera}

Murine typhus serum. Pooled sera from guinea-pigs bled about 30 days after infection with the Wilmington strain.

Classical typhus serum. Obtained from a guinea-pig infected with a yolk-sac suspension of the Breinl strain and bled 30 days later.

$Q$ fever serum. Guinea-pig immune serum kindly supplied by the late Dr R. R. Parker, from the Rocky Mountain Laboratory, Hamilton, Montana.

Proteus antisera. Obtained from human cases of murine typhus, from pregnant women, and from a rabbit immunized with an ethanolic suspension of Proteus OX 19.

\section{Measurement of opacity}

The density of the suspensions was determined by the light extinction observed in a Klett-Summerson photoelectric colorimeter with a 54 filter. A special holder was adapted to take standardized $13 \times 100 \mathrm{~mm}$. tubes. The 
window was slightly reduced to allow the use of $1 \mathrm{ml}$. volumes. Within the region in which we worked, a linear relationship was obtained between the concentration of the suspension and the light extinction, as seen in Table 1 in which the light extinctions of various concentrations of a Proteus OX 19 suspension are given. The value of $100 \%$ was chosen arbitrarily to give a reading of approximately 100.

Table 1. Opacity measurements of Proteus $O X 19$ suspensions

$\begin{array}{cccc}\begin{array}{c}\text { Suspension } \\ (\mathrm{ml})\end{array} & \begin{array}{c}\text { Saline } \\ (\mathrm{ml})\end{array} & \begin{array}{c}\text { Luspension } \\ (\%)(x)\end{array} & \begin{array}{c}\text { Light } \\ \text { extinction }\end{array} \\ 0 \cdot 1 & 0 \cdot 9 & 10 & (y) \\ 0 \cdot 2 & 0 \cdot 8 & 20 & 9 \\ 0 \cdot 3 & 0 \cdot 7 & 30 & 19 \cdot 5 \\ 0 \cdot 4 & 0 \cdot 6 & 40 & 30 \cdot 5 \\ 0 \cdot 5 & 0 \cdot 5 & 50 & 41 \\ 0 \cdot 6 & 0 \cdot 4 & 60 & 52 \\ 0 \cdot 7 & 0 \cdot 3 & 70 & 60 \\ 0 \cdot 8 & 0 \cdot 2 & 80 & 70 \\ 0 \cdot 9 & 0 \cdot 1 & 90 & 81 \\ 1 \cdot 0 & - & 100 & 92 \\ & & & 99\end{array}$

The parameters of the line $y=b x+a$ gave values of 0.154 and 0.99 respectively for $a$ and $b$, allowing the direct reading of the percentage of bacteria in suspension from the light extinction.

For economy, less concentrated rickettsial suspensions were used and the $100 \%$ density was standardized to give a light extinction reading of 50. The same linear relationship was observed as in bacterial suspensions, and the percentages of rickettsias were given by the light extinction readings multiplied by 2 .

\section{Serial dilution tests}

\section{Agglutination methods}

Serial twofold dilutions of the serum were made in saline and an equal volume of the suspension was added. Proteus OX 19 agglutination was done in $12 \times 75 \mathrm{~mm}$. tubes with a total volume of $1 \mathrm{ml}$. and the rickettsial agglutinations in $10 \times 75 \mathrm{~mm}$. tubes with a total volume of $0.2 \mathrm{ml}$. The tests were incubated in a water-bath at $37^{\circ}$ for $2 \mathrm{hr}$. and left overnight at $4^{\circ}$. The titres represent the highest final dilution of serum causing definite agglutination. The $50 \%$ end-points were calculated according to the method described by Hedén (1946). The density of all the suspensions was adjusted to give a light extinction reading of about 85 .

\section{Quantitative agglutination test}

$0 \cdot 1 \mathrm{ml}$. volumes of the suspension were distributed with a $0.2 \mathrm{ml}$. pipette at the bottom of a series of standardized $13 \times 100 \mathrm{~mm}$. tubes. Increasing volumes (in arithmetical progression) of an appropriate dilution of serum were added and the volumes in all tubes were made up to $1 \mathrm{ml}$. with buffered saline. The control tube received $0.1 \mathrm{ml}$. of the suspension and $0.9 \mathrm{ml}$. of buffered 
saline. The tubes were shaken, left to stand for a few minutes, and the light extinctions were read with the photoelectric colorimeter to check the $100 \%$ density. The tubes were then incubated in a water-bath at $37^{\circ}$ for $2 \mathrm{hr}$. and were then centrifuged in a horizontal centrifuge at a speed previously determined to yield $50 \%$ sedimentation within 10 and 20 min. (about 2200 r.p.m. for rickettsial suspensions and 1000 r.p.m. for bacterial suspensions). After each $5 \mathrm{~min}$. period the tubes were carefully removed from the centrifuge and the light extinctions determined with the photoelectric colorimeter. Centrifugation was continued until over $50 \%$ of the organisms in the control tube were deposited; usually three or four periods of 5 min. were sufficient (Table 2). The tubes were then centrifuged at high speed for all the organisms to be deposited, and the light extinctions of the supernatants were read; these values were deducted from the previous readings obtained with the corresponding tubes to eliminate error introduced by haemolysis or opalescence of the sera. The percentage of organisms deposited after each period of centrifugation was calculated and plotted against time. The $50 \%$ sedimentation times $(T 50)$ were read from the curves (Fig. 1). The $T 50$ of the control was adopted as the unit time $(U)$ and the relative $50 \%$ sedimentation times $(T)$ were given by the relation $T 50 / U$, which may vary from very nearly $O$ (complete agglutination) to 1 (absence of agglutination). The relative $50 \%$ sedimentation times plotted against the amounts of serum $(S)$ gave points approximately on a straight line (Figs. 2-5), and the reaction may be expressed by the equation $T=b S+a$. The agglutination unit was defined as the amount of serum giving a relative $50 \%$ sedimentation time of 0.5 , that is, an amount of serum with which the $50 \%$ sedimentation time is half that of the control. This unit was obtained from the line $T=b S+a$; the parameters $a$ and $b$ were calculated by the method described by de Almeida (1951).

Table 2. Quantitative agglutination test with Proteus $O X 19$

\begin{tabular}{|c|c|c|c|c|c|c|c|c|}
\hline \multirow[b]{2}{*}{$\begin{array}{l}\text { Suspension } \\
\text { (ml.) }\end{array}$} & \multirow{2}{*}{$\begin{array}{c}\text { Serum } \\
1 / 200 \\
\text { (ml.) }\end{array}$} & \multirow[b]{2}{*}{$\begin{array}{c}\text { Saline } \\
\text { (ml.) }\end{array}$} & \multirow{2}{*}{$\begin{array}{l}\text { Serum } \\
\text { concen- } \\
\text { tration } \\
(\mathrm{ml} .)(S)\end{array}$} & \multicolumn{3}{|c|}{ Sedimentation } & \multirow[b]{2}{*}{ T 50* } & \multirow[b]{2}{*}{$\begin{array}{c}T 50 / U \dagger \\
(T)\end{array}$} \\
\hline & & & & 5 min. & 10 min. & $15 \mathrm{~min}$. & & \\
\hline $0 \cdot 1$ & 0.4 & $0 \cdot 5$ & $0 \cdot 0020$ & 27 & 43 & 56 & $12 \cdot 5$ & 0.86 \\
\hline 0.1 & 0.5 & $0 \cdot 4$ & $0 \cdot 0025$ & 31 & 48 & 61 & $10 \cdot 5$ & $0 \cdot 72$ \\
\hline $0 \cdot 1$ & $0 \cdot 6$ & $0 \cdot 3$ & $0 \cdot 0030$ & 38 & 56 & 70 & $8 \cdot 5$ & 0.58 \\
\hline $0 \cdot 1$ & $0 \cdot 7$ & $0 \cdot 2$ & 0.0035 & 41 & 61 & 72 & $6 \cdot 5$ & 0.44 \\
\hline $0 \cdot 1$ & - & 0.9 & $\longrightarrow$ & 18 & 38 & 52 & $14 \cdot 5$ & - \\
\hline
\end{tabular}

\section{RESULTS \\ Agglutination of rickettsias}

$Q$ fever immune guinea-pig serum, with a titre of 1/1280 by the dilution method, showed by the quantitative method an agglutination unit of 0.00075 (1333 units $/ \mathrm{ml}$.). The relative sedimentation times plotted against the amounts of serum gave points approximately on a straight line with a regression coefficient of -628 . 
Murine and classical typhus sera were tested against both the homologous and the heterologous suspensions; the results are shown in Table 3 and in Figs. 3 and 4.

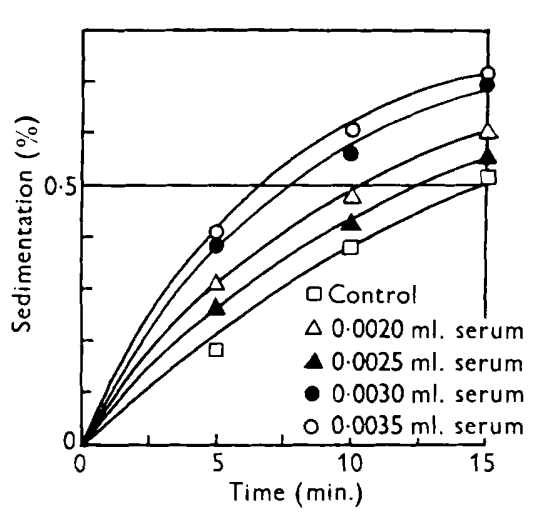

Fig. 1. Sedimentation curves of Proteus OX 19 suspension in the presence of varying amounts of agglutinating serum. (From Table 2.)

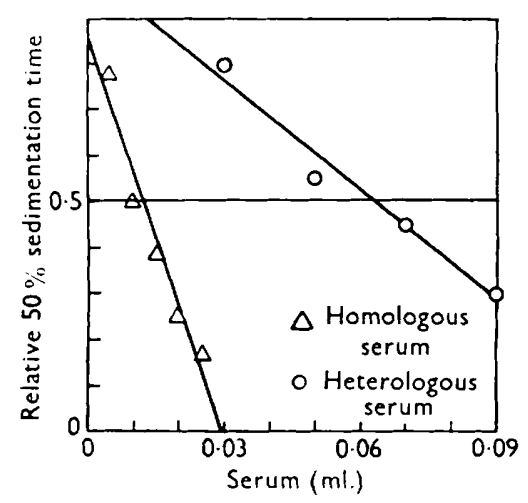

Fig. 3. Agglutination of murine typhus rickettsias by murine and classical typhus sera.

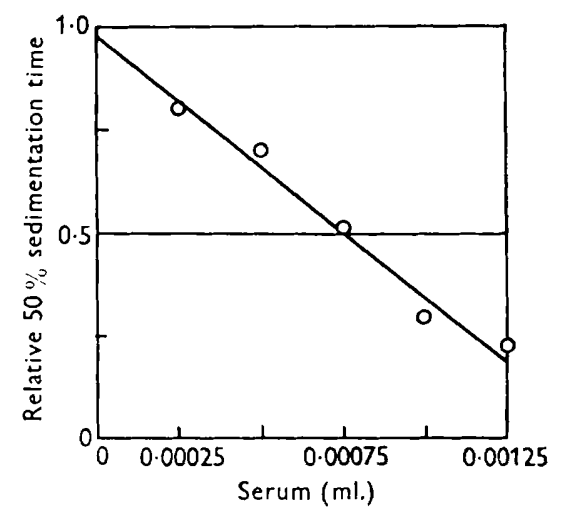

Fig. 2. Agglutination of $Q$ fever rickettsias of homologous serum.

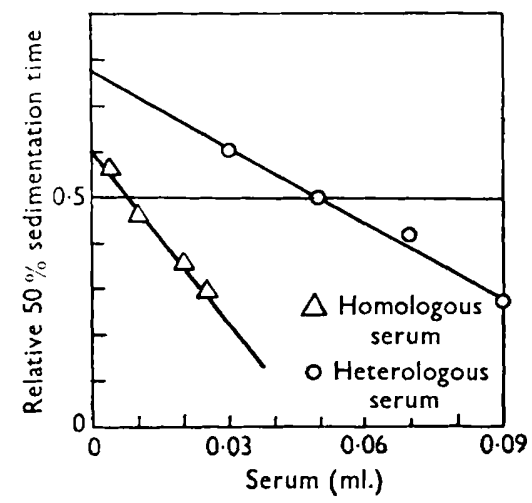

Fig. 4. Agglutination of classical typhus rickettsias by classical and murine typhus sera.

Table 3. Agglutination of murine and classical rickettsias by homologous and heterologous sera

\begin{tabular}{|c|c|c|c|c|c|}
\hline \multirow[b]{2}{*}{ Serum } & \multirow[b]{2}{*}{ Antigen } & \multirow{2}{*}{$\begin{array}{l}\text { 'Titre } \\
\text { by dilution } \\
\text { method }\end{array}$} & \multicolumn{3}{|c|}{ Quantitative method } \\
\hline & & & $\begin{array}{l}\text { Agglutination } \\
\text { unit }\end{array}$ & Units/ml. & $\begin{array}{c}\text { Regression } \\
\text { coefficient }\end{array}$ \\
\hline Murine & Murine & $1 / 80$ & 0.012 & $83 \cdot 3$ & $-29 \cdot 4$ \\
\hline Classical & Murine & $1 / 40$ & 0.0625 & $16 \cdot 0$ & $-8 \cdot 0$ \\
\hline Murine & Classical & $1 / 20$ & 0.05 & $20 \cdot 0$ & $-5 \cdot 2$ \\
\hline Classical & Classical & $1 / 80$ & 0.0085 & $117 \cdot 6$ & $-12 \cdot 5$ \\
\hline
\end{tabular}


It was possible to differentiate the two systems by both the quantitative and the serial dilution methods. The former method allowed a clear differentiation by two characteristics: the agglutination unit, which was always lower for the homologous than for the heterologous systems; and the regression coefficient, with higher values for the homologous than for the heterologous systems.

In the serial dilution method, both sera gave titres of $1 / 80$ with the homologous antigens and lower titres with the heterologous antigens; the differences however, were of the order of one or two dilutions, and, in view of the difficulty

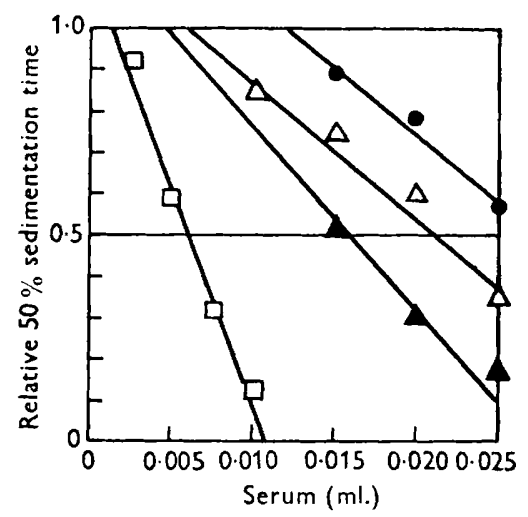

Fig. 5. Agglutination of Proteus OX 19 by sera of different origins. $\square$, rabbit Proteus antiserum; $\Delta$, murine typhus serum; $\triangle$, pregnancy serum $A ; \boldsymbol{O}$, pregnancy serum $B$.

in reading the finer degrees of agglutination, the end-point was not always easy to define. We found the estimation of the $50 \%$ end-point (Hedén, 1946) to be impractical in rickettsial agglutination tests because of the difficulty in distinguishing five or even four different grades of agglutination.

\section{Agglutination of Proteus OX 19 (Weil-Felix test)}

In Table 4 we give the results of the serial dilution and of the quantitative agglutination methods obtained with four sera, all of which gave a titre of $\mathbf{1} / \mathbf{3 2 0}$ by the first method.

Table 4. Agglutination of Proteus $O X 19$ by sera of different origins

\begin{tabular}{|c|c|c|c|c|c|}
\hline \multirow[b]{2}{*}{ Sera } & \multicolumn{2}{|c|}{ Dilution method } & \multicolumn{3}{|c|}{ Quantitative method } \\
\hline & Titre & $\begin{array}{c}50 \% \\
\text { end-point }\end{array}$ & $\begin{array}{c}\text { Agglutination } \\
\text { unit }\end{array}$ & Units $/ \mathrm{ml}$. & $\begin{array}{c}\text { Regression } \\
\text { coefficient }\end{array}$ \\
\hline Rabbit Proteus antiserum* & $1 / 320$ & $1 / 201$ & $0 \cdot 006$ & 166 & -107 \\
\hline Murine typhus & $1 / 320$ & $1 / 226$ & $0 \cdot 016$ & 62 & $-44 \cdot 4$ \\
\hline Pregnancy A & $1 / 320$ & $1 / 201$ & 0.021 & 47 & -33 \\
\hline Pregnancy B & $\mathbf{1} / \mathbf{3 2 0}$ & $1 / 127$ & 0.027 & 37 & -32 \\
\hline
\end{tabular}

* 1/32 dilution of a rabbit Proteus antiserum with an original agglutination titre of $1 / 10,240$. 
The quantitative method clearly distinguished these sera both by the agglutination unit and by the regression coefficient, the latter providing a particularly clear distinction (Fig. 5). A certain correspondence was observed between the values obtained for the $50 \%$ end-points calculated according to Hedén (1946) and those obtained by the quantitative method, except in the case of the rabbit immune serum in which the $50 \%$ end-point was low in relation to the agglutination unit and to the slope.

\section{DISCUSSION}

The linear relationship between the degree of agglutination, judged by the relative $50 \%$ sedimentation time, and the amounts of serum, provides valuable information for the study of the agglutination reaction. The activity of sera studied by this method may be expressed by two characteristics: the agglutinin content, represented by the agglutination unit; and the agglutinating capacity, represented by the slope $(b)$ of the time $(T)$-serum $(S)$ regression line $T=b S+a$.

In this respect, our results are analogous to those obtained with the quantitative complement-fixation test, in which the complement-fixing capacity of certain systems is better expressed by the slope of the complementantigen and complement-serum regression lines (Rice, 1946; Wolfe \& Kornfeld, 1949).

From our results with Proteus OX 19 agglutination, it is interesting to note that in the case of sera of the same origin (pregnancy) the time-serum regression lines show a striking parallelism (Fig. 5), whereas a comparison of the sera of different origins reveals an increasing slope corresponding to increasing specificity of the reaction. These results are in agreement with the view that the Weil-Felix reaction is due to the presence, in the sera of typhus patients, of an antibody reacting with one of the antigenic groupings of Proteus OX 19 (Weil \& Felix, 1921; White, 1933; Castaneda, 1935). They also agree with the observation that the agglutination of Proteus OX 19 by sera from pregnant women is due to a factor distinct from that in sera from typhus patients, as shown by indirect evidence by Travassos, de Gois, Pereira \& Bruno-Lobo (1951).

From the results obtained, it may be expected that the application of the present method to the study of other groups of micro-organisms will be of value in providing evidence of inter-group antigenic differences. The method may, with the help of analytical centrifuges, also prove to be of use in the study of the antigenic structure of the smaller viruses. Its use as a routine serological test requires further investigation.

In the case of a few sera tested against rickettsial suspensions, a time-serum linear relationship was not observed. The same sera showed in serial dilution tests a wide range of dilutions with partial agglutination. The significance of these results was not investigated.

We wish to express our thanks to Dr Horacio Cintra for his valuable help and criticism in the course of this work. 


\section{REFERENCES}

Almeida, M. O. DE (1951). Sur la calcul des paramètres des equations de la forme $y=a x+b$. Ann. Acad. bras. de Ciencias, 23, 421.

Bridges, R. F. (1944). Notes on the preparation of suspensions for the Weil-Felix test. Trans. R. Soc. trop. Med. Hyg. 37, 343.

Castaneda, M. R. (1935). 'The antigenic relationship between Bacillus proteus X19 and Rickettsiae. III. A study of the antigenic composition of extracts of Bacillus proteus X19. J. exp. Med. 62, 289.

HEDÉN, C.-G. (1946). On the estimation of fifty per cent end-points in serological titrimetry. J. Path. Bact. 58, 477.

Heidelberger, M. \& Kabat, E. A. (1934a). Chemical studies in bacterial agglutination. I. A micro-method for the quantitative estimation of agglutinins. Proc. Soc. exp. Biol., N.Y. 31, 595.

Heidelberger, M. \& Kabat, E. A. (1934b). Chemical studies on bacterial agglutination. I. A method. J. exp. Med. 60, 643.

Hirst, G. K. \& Pickles, E. G. (1942). A method for the titration of influenza hacmagglutinins and influenza antibodies with the aid of a photoelectric densitometer. J. Immunol. 45, 273.

KABAT, E. A. \& MAYER, M. M. (1948). Experimental Immuno-chemistry. Springfield, Illinois: Charles C. Thomas.

Kent, J. F., Bukants, S. C. \& Rein, C. R. (1946). Studies in complement-fixation. I. Spectrophotometric titration of complement; construction of graphs for direct determination of the 50 per cent hemolytic unit. J. Immunol. 53, 37.

Reed, L. J. \& Muench, H. (1938). A simple method of estimating fifty per cent end-points. Amer. J. Hyg. 27, 493.

Rice, C. E. (1946). Studies of the complement-fixation reaction in virus systems. I. Activities of vaccinia virus antigens and antisera. J. Immunol. 53, 225.

Topping, N. H. \& ShePard, C. C. (1946). The preparation of antigens from yolk sacs infected with Rickettsiae. Publ. Hlth Rep., Wash. 61, 701.

Trayassos, J., de Gois, P., Pereira, H. G. \& Bruno-Lobo, M. (1951). Comportamento immunologico de soros de gravidas de cance-nosos sobre O Proteus OX19 e Rickettsiae. Ann. Microbiol., Rio de Janeiro, 1, 21.

Weil, E. \& Felix, A. (1921). Über die Beziehungen der Fleckfieberagglutination zum Fleckfiebererreger. Z. ImmunForsch. 31, 457.

Wirte, P. B. (1933). The O-receptor complex of B. proteus X19. Brit. J. exp. Path. $14,145$.

Wolfe, D. M. \& Konnfeld, L. (1949). The application of a quantitative complement fixation method to a study of $\mathrm{Q}$ fever strain differentiation. J. Immunol. 61, 297. 